\title{
Covid-19 Salgını Sürecinin İşgücü Piyasaları Üzerine Etkisi: Uygulamalı Bir Araştırma İlkay NOYAN YALMAN ${ }^{1}$ - Esra AYDIN ÜNAL ${ }^{2}$
Şerife Merve KOŞAROĞLU
}

\begin{tabular}{ccc}
\hline Geliş Tarihi/ Received & Kabul Tarihi/ Accepted & Yayın Tarihi/ Published \\
29.03.2021 & 25.06.2021 & 15.07 .2021 \\
\hline Citation/Atıf: Noyan Yalman, I., Aydın Ünal E. ve Koşaroğlu, Ş. M., (2021), Covid-19 Salginı Sürecinin \\
İşücü Piyasaları Üzerine Etkisi: Uygulamalı Bir Araştırma, Atatürk Üniversitesi İktisadi ve İdari Bilimler \\
Dergisi, 35(3): Sayfa: $1125-1144$, https://doi.org/10.16951/atauniiibd.905180 \\
\hline
\end{tabular}

Öz: İnsan sağlığı ve hayatıyla ilgili endişelerin giderek artmasına neden olan Covid-19 salgını sürecinden, dünya ekonomilerinin önemli ölçüde etkilendiği görülmüştür. Salgın döneminde, dünyanın en gelişmiş ekonomileri de dahil olmak üzere, pek çok ekonomi son yılların en büyük daralma sürecine girmiştir. Bu durum Covid-19 salgınının, ülke ekonomilerine yaptığ 1 etkiler ve geri toparlanmanın ne kadar süreceği gibi konularda büyük merak oluşturmuştur. Temel olarak Covid-19 salgınını kontrol altına almak için alınan tedbirler, çoğu sektörde üretimin durma noktasına gelmesine yol açarak işgücü piyasalarını derinden etkilemiştir. Salgın döneminde dünyada rekor düzeyde işsizlik artışı olmuştur. Bununla birlikte, salgın sürecinde nitelik olarak uygun olan bazı sektörlerde dijitalleşme doğrultusunda evden çalışma olgusunun ön plana çıktığı görülmüştür. Bu çerçevede, Covid-19 salgını döneminde işgücü piyasalarında ortaya çıkan eğilimleri belirlemek üzere bir anket çalışması yapılmıştır. Elde edilen sonuçlara göre, salgının yol açtığı arz şoku, işgücü talep ve arzının yanı sıra işgücü piyasasının işleyişini de etkilemiştir. Anahtar Kelimeler: Covid-19 Salgını, Salgın Ekonomisi, İşgücü Piyasası.

The Effect of Covid-19 Epidemic Process on Labor Markets: An Applied Research

Abstract: It has been observed that the world economies have been significantly affected by the Covid-19 epidemic process, which has caused increasing concerns about human health and life. During the epidemic period, many economies, including the most developed economies of the world, have entered the biggest recession in recent years. This situation has created great curiosity about effects of the Covid-19 epidemic on the economies of the country and how long the recovery will take. Basically, the measures taken to contain the Covid-19 epidemic have deeply affected the labor markets by causing production to come to a halt in most sectors. During the epidemic period, there was a record increase in unemployment in the world. However, in some sectors that are qualitatively suitable, it has been observed that working from home has come to the fore in the direction of digitalization. In this context, survey questions were prepared to determine the trends in the labor markets during the Covid-19 epidemic. The results obtained were that the supply shock caused by the epidemic affected the demand and supply of labor as well as the functioning of the labour market.

Keywords: Covid-19 Epidemic, Epidemic Economy, Labor Market.

JEL Codes: I18, J21, J01.

${ }^{I}$ Doç. Dr., Sivas Cumhuriyet Üniversitesi, İktisadi ve İdari Bilimler Fakültesi, Ekonometri Bölümü, iyalman@cumhuriyet.edu.tr, https://orcid.org/0000-0003-2999-5374

${ }^{2}$ Dr. Öğr. Üyesi, Sivas Cumhuriyet Üniversitesi, Zara Veysel Dursun Uygulamalı Bilimler Yüksekokulu, Sigortacllık ve Risk Yönetimi Bölümü, eaunal@cumhuriyet.edu.tr, https://orcid.org/0000-0002-1613-2046

${ }^{3}$ Dr. Ögr. Üyesi, Sivas Cumhuriyet Üniversitesi, Cumhuriyet Sosyal Bilimler Meslek Yüksekokulu, FinansBankaclllkve SigortacllıBBölümü, mkosaroglu@cumhuriyet.edu.tr, https://orcid.org/0000-0002-2563-5753 


\section{Background}

\section{EXTENDED SUMMARY}

The health crisis that emerged with the Covid-19 epidemic also caused important crises in the field of economy. Even if various subsidies were provided with government supports to eliminate or reduce the effects of the supply shock caused by the epidemic, the expected positive effects in the economies were seen at a limited level. Expectations are increasing that the economic problems caused by the Covid-19 epidemic will continue in the following years, since sufficient positive results could not be obtained from the measures taken.

\section{Purpose}

The main purpose of this study is to be able to produce a policy to evaluate and improve its economic dimension by investigating the problems and changes in the labor markets during the Covid-19 epidemic. Well definition of the economic problems that occur during the epidemic process is necessary for correct policy choices, and it is thought to be very important in terms of overcoming this process in a shorter time.

\section{Method}

In the study, a survey was conducted to determine the characteristics of the labor market during the Covid-19 epidemic. The prepared survey questions were applied on the active population in the cities of Ankara, Kayseri, Konya, Sivas, Malatya, Yozgat. It was assumed that the active population, which was the source of the study, perceived the questionnaire questions correctly and answered them appropriately. In the study, the online survey method was preferred due to the ongoing risk of transmission of the virus. The questionnaires were evaluated using the SPSS23 package program.

\section{Findings}

The main findings from the study are as follows:

The Covid-19 epidemic caused significant losses in terms of labor supply. The fact that the sick people stay away from the market due to the virus infection and / or those who cannot recover and die from the labor market have caused a contraction in the labor supply. On the other hand, the fact that production has come to a halt in many segments has also narrowed the demand for labor.

The disruption of the global supply chain due to the Covid-19 epidemic caused significant disruptions in production and negatively affected the labor market.

While there was a great loss in certain sectors during the Covid-19 epidemic, it was observed that employment activities could be carried out with the opportunity to work from home in some sectors. Although works are carried out under these conditions; it is observed that the problems on issues such as working time, authority area, overtime concept or overtime payments are increasing. However, adaptation problems in making and implementing legal regulations make it difficult for flexibility in this sense in the labor market. 
Compulsory distance education of educational activities will result in insufficient vocational education and skills in the future.

\section{Conclusions}

The Covid-19 epidemic has affected the labor markets in various ways. The predictions that the short-term and home-based working styles expected in the business world, especially in the private sector, will increase in the future are not supported in the analysis. The majority of those participating in the research state that productivity, motivation and production will decrease. These views also arise due to the individuals' anxiety about being unemployed and loss of rights. Accordingly, if home-based and flexible work becomes widespread in the future, the physical and legal infrastructure of this should be established. It may cause negative consequences in matters such as the decrease in the duration of meetings with colleagues and managers, the inability to share knowledge and experiences, or the weakening of the strength of the organizational culture. In the periods after the epidemic, adaptation processes can be experienced in order to rearrange the relations between employees and managers.

\section{Giriş}

Corona virüs (Covid-19), ilk olarak Aralık 2019'da Çin'in Wuhan kentinde tanımlanmış ve 2020 yılı başında küresel salgına dönüşmüştür. Dünyada büyük şaşkınlık yaratan bu salgın, SARS ile ilgili bir virüsten kaynaklanmakla birlikte, SARS'tan çok daha yüksek sayıda ölümlere neden olmuştur. Nisan 2021 itibari ile dünyada 144 milyonu geçen vaka ve 3 milyonu geçen ölüm sayısı, Covid-19 salgınının ağır bilançosunu yansıtmaktadır (WHO, 2021). Birçok devlet salgının başlandığ 1 ilk dönemlerde, Covid-19'un geçici olduğunu düşünerek hastalığa karşı yeterli tedbir almamıştır. Ancak, salgından kısa bir süre sonra Covid-19'un, SARS'dan çok daha bulaşıcı olduğu anlaşılmıştır (Piguillem ve Shi, 2020:1; Chao, 2020:1). Bu durumun başlıca nedeni olarak, günümüzde ulaşım ağının gelişmesine bağlı olarak ülkeler arası giriş ve çıkışların kolaylaşması gösterilmektedir. Dolayısıyla ulaşımın getirdiği avantajlar bu noktada, Covid-19 salgınının tarihte görülen çoğu salgından daha hızlı bir yayılım göstermesine neden olmuştur (Yılmaz, 2020:1725). Virüsün yayılma hızı ve şiddetinden dolay1, Covid-19 küresel sağlik krizine dönüşmüş ve toplumsal hayatta sert tedbirlerin uygulanmasını zorunlu kılmıştır. Birçok devlet Covid-19 salgınını kontrol edebilmek için seyahat kısıtlamaları, ev karantinaları, kamusal alanların, okulların ve zorunlu olmayan işletmelerin kapatılması, işçiler arasında yakın fiziksel temasa neden olan ekonomik faaliyetlerin kısıtlanması gibi tedbirler almıştır (Baker vd., 2020:6). Bu tür kısıtlamalar, virüsün yayılımını yavaşlatmak ve insan hayatını kurtarmak için önemli bir adım olarak kabul edilse de bu kısıtlamaların ekonomik maliyetleri yüksek olmuştur (Barrot vd., 2020:2; Piguillem ve Shi, 2020:1). Bu maliyetlerin bazıları da işgücü piyasalarında ortaya çıkmıştır. Gerek üretimin yavaşlaması gerekse salgın endişesiyle çalışanların işlerini bırakması sonucu, işgücü piyasasında ve buna bağlı olarak çalışma 
hayatında önemli değişimler ortaya çıkmıştır. Bunlarla birlikte, salgın sürecinin bütün sektörleri eşit olarak etkilememesi, istihdam açısından firsatlar ya da tehditler oluşturmuştur. Bazı işletmelerin çalışanlar arasında salgın riskini önleyecek şekilde uzaktan çalışma yoluyla faaliyetlerine devam edebilmesi önemli avantaj sağlarken, diğer pek çok işletme için bu durum söz konusu olmamıştır. Hem işin doğası hem de yönetim kapasitesi gibi çeşitli nedenlerden dolayı, Covid-19 salgını bazı sektörler için önemli tehditler oluşturmaktadır. İşletmelerin işleyişleri arasındaki farklılıklar, salgının sürekliliğine bağlı olarak, işsizlik rakamlarına yansımaktadır (Bartik vd., 2020:13-14). Dolayısıyla, Covid19 salgınının, çalışma hayatı ve işgücü piyasalarında oluşturduğu etkiler çok boyutlu olmakla birlikte, salgın sürecinin devam etmesi ve belirsizliğini koruması nedeniyle de bunların kısa vadede çözümü oldukça zor görülmektedir. Bu noktada, işgücü piyasası olumsuzluklarından dezavantajlı ve zayıf olan grupların daha kolay ve çok etkilenmesi, işlerin ve iş kalitesinin azalması gibi sonuçların işgücü piyasasında görülen en belirgin etkiler olarak ortaya çıkması beklenmektedir. Covid-19 salgını, normalde görülen iş veren ve çalışanlar arasındaki çatışmanın daha da artmasına neden olacaktır (Yorğun, 2020:105106).

$\mathrm{Bu}$ çalışmanın temel amacı, Covid-19 salgını döneminde işgücü piyasalarında görülen sorunların ve değişimlerin araştırılarak, ekonomik boyutunun değerlendirilmesi ve iyileştirilmesi yönünde politika üretebilmektir. $\mathrm{Bu}$ amaç doğrultusunda, mevcut salgın koşullarında piyasada yaşananlar gözlemlenerek anket formu hazırlanmış ve Orta Anadolu'da seçilmiş illerde çalışma çağındaki nüfusa uygulanmıştır. Yapılan analiz sonucunda salgının işgücü piyasaları üzerindeki etkileri belirlenmeye çalışılmış ve bu süreçte uygulanan kamu desteklerinin etkinliği araştırılmıştır. Çalışmada özellikle salgın sonrası dönemde çalışma hayatındaki değişimler ve işgücü piyasalarının alacağı yön hakkında öngörüler sunulmuştur. Bu yönüyle özgünlük taşıyan çalışmanın, literatüre katkı sağlayacağı düşünülmektedir.

\section{Covid-19 Salgınının Dünya Ekonomisine Etkileri}

Covid-19 salgını nedeniyle küresel ekonomi, Büyük Buhran'dan bu yana en derin ekonomik durgunluk sürecine girmiştir (OECD, 2020b:12). Covid-19 salgını, gelişmiş ve gelişmekte olan ülkeleri etkisi altına alarak, çoğu dünya ekonomisi üzerinde etkili olmuştur. Salgının dünya genelinde birçok kanaldan etkisini göstererek yayılması, küresel ekonomik faaliyetlerin keskin şekilde daralmasina neden olmuştur (TCMB, 2020:1).

Dünyada Covid-19 salgınından hizmetler ve imalat sanayii sektörlerinin önemli düzeyde etkilediği görülmektedir. Covid-19 kaynaklı ekonomik problemlerin derinleşmesine sebep olan ve ekonomileri derin bunalım sürecine sokan durum, salgının neden olduğu arz şoku, bir yandan işgücü arz şokuna yol açarken diğer yandan da daha büyük bir talep şokuna yol açmıştır (Guerrieri vd., 2020:2). Zorunlu karantina döneminde başta üretimin aniden kesintiye uğraması 
ve küresel tedarik zincirindeki aksaklıklar olmak üzere gelişmeler küresel arz şokuna neden olmuştur (Rio-Chanona vd., 2020:69). Covid-19 salgını insanların hareketliliği yoluyla yayılırken, ekonomik şoklar ülkeler arasında temelde ticaret bağlantıları yoluyla yayıldığı için salgın küresel ekonomik sonuçlar ortaya çıkarmıştır. Günümüzde uluslararası ticaret, dünya ticaretinin üçte ikisini temsil eden ara mal ticaretiyle giderek büyümektedir. Ara ürünlerde ticaretin büyümesi, küresel tedarik zincirlerinin gelişimi ile açıklanmaktadır. Zincirin bir noktasındaki herhangi bir üretim kesintisi, üretim süreçlerinin büyük oranda etkilenmesine neden olmaktadır. Buna göre, Covid-19 salgınının ilk olarak görüldügü Çin'de meydana gelen üretim kesintileri, küresel tedarik zincirlerinde büyük bir aksamaya neden olmuştur (Gerschel vd., 2020:2). Bu durumu, 2000 yılından bu yana dünyada Çin girdilerine olan talep artışlarıyla açıklamak mümkündür. Buna göre, çoğu ülke hem doğrudan Çin girdilerinin ithalatı yoluyla hem de dolaylı olarak Çin'in katma değeri ile üretilen diğer girdiler aracılığıyla küresel tedarik zincirinde Çin hakimiyeti sağlanmıştır. Çin'de salgın nedeniyle oluşan üretim yavaşlaması ise diğer ülkelerde önemli tedarik sürecinin aksamasına yol açmıştır. Bu aksaklıklar ise büyük bir arz şokuna neden olmuştur (Gerschel vd., 2020:1; Karagöz, 2020:75).

Salgınların yol açtığı yaygın ölümler, toplumdaki genç ve yaşlı nüfus oranının değişmesine yol açarak beşeri sermayenin üstünde etkili olmaktadır (Yılmaz, 2020:1725). Dolayısıyla salgınlardan kaynaklanan arz şoklarının bir boyutu da işgücü arz şoku şeklinde ortaya çıkmaktadır. Covid-19'un, ölüm ve enfeksiyona bağlı hastalığa neden olması, bu noktada doğrudan işgücü kaybı anlamına gelmektedir (Rio-Chanona vd., 2020:69). Covid-19 nedeniyle iş yeri kapanışları dünya çapında işgücü piyasalarını bozmaya devam ederek, tahmin edilenden daha yüksek çalışma saati kayıplarına yol açmıştır. Çalışma saati kayıpları, daha yüksek işsizlik ve aktivite eksikliğine neden olmaktadır. İstihdam rakamlarındaki düşüş genel olarak kadınlarda erkeklere göre daha fazla olmuştur. Dolayısıyla bu yüksek çalışma saati kayıpları, işgücü gelirinde önemli kayıplara dönüşmüş̧ür. İşgücü gelir kayıplarının en yüksek olduğu ülkeler ise, orta gelirli ülkeler olmuştur (ILO, 2020:1-2). Salgının neden olduğu olumsuz arz şokları başlıca üretim ve istihdamın olumsuz etkilenmesine neden olmuştur. Ekonominin arz tarafina etki eden kuvvetler, talep tarafını etkileyen mekanizmaları ortaya çıkarmaktadır. Buna göre, çalışanların arz şoku nedeniyle işlerini kaybetmesi sonucu yaşadıkları gelir kaybı, harcamalarını azaltmalarına ve bu durumun toplam talep düzeyinde daralmaya, yani talep şokuna neden olmaktadır. Böylece, oluşan arz şokunun büyüklüğü, kendisinden daha büyük bir daralmaya yol açan talep eksikliğini tetikleyerek ekonomik bunalım sürecini beslemektedir (Guerrieri vd., 2020:2). Covid-19 salgını sürecinin neden olduğu arz şoku ise, talep düzeyinde değişime yol açacak kadar güçlü olmuştur.

Covid-19 salgınının fiyat istikrarının bozulması yönünde ortaya koyduğu eğilimler dikkatleri çekmiştir. Bu noktada özellikle arz ve talep şoklarının fiyatlar üzerinde oluşturduğu baskılar, artan belirsizlik düzeyi, uygulanan canlandırıcı 
politikaların finansmanı açısından küresel düzeyde fiyatlar üzerindeki baskı artmıştır. Özellikle gelişmiş ve gelişmekte olan ülkelerde hisse senedi ve tahvil piyasalarında ciddi dalgalanmaların olduğu gözlenmiştir. Covid-19 salgını nedeniyle gelişmekte olan ülkelerden yoğun sermaye çıkışı yapılmıştır. Bu durum ülkelerin risk primlerini yükseltirken, ulusal paraların değer kaybetmesine yol açmıştır (TCMB, 2020:7). Sebep olduğu finansal etkilerde göz önüne alındığında, Covid-19 salgınının küresel ekonomi üzerindeki derin etkisi izlenebilmektedir.

\section{Covid-19 Salgını Döneminde Türkiye Ekonomisi}

Genel olarak ekonomik göstergeler değerlendirildiğinde, Covid-19 salgının Türkiye ekonomisi üzerinde önemli etkiler oluşturduğu gözlemlenmiştir. Salgın sürecinde, dünya ekonomilerindeki benzer sorunlar, Türkiye ekonomisinde de ortaya çıkmıştır. Türkiye'de sağlık alt yapısının yeterli olması ve sağlık çalışanlarının özverili çabalarıyla salgın kontrol altında tutulmaya çalışılmıştır. Devletin bu konuda aldığ kısıtlayıcı önlemler bunu desteklemiştir. Salgından olumsuz olarak etkilenen birimlere ekonomik olarak çeşitli destek paketleri uygulamaya konmuştur. Salgının başlamasıyla birlikte devlet, özel yaş grupları, bazı şehirler ve çeşitli özel bölgelere sokağa çıkma yasakları getirmiştir. İdari kararla kapatılan sektörlerin faaliyetlerinin durdurulması, resmi tatil ve hafta sonlarında ulusal sokağa çıkma yasağının getirilmesi nüfusun büyük bir kısmının hareketlerini kısıtlamıştır. Bunların yanı sıra uluslararası ve yurtiçi yolcu trafiği kapatılarak bölgeler arasında karantina uygulamalarına gidilmiştir. Türkiye'de 11 Mart 2020 tarihinde ilk Covid-19 vakası görülmüştür (OECD, 2020b:320). Geçen bir yılı aşkın sürede vaka ve ölüm rakamlarının üç kez büyük sıçrama yaptığı görülmüştür. Üçüncü artışta 2021 Nisan ayı itibariyle günlük 60 bini geçen vaka ve artan ölüm sayıları, kısıtlamaların artırılmasıyla kontrol altına alınmaya çalışılmaktadır. Bu durum salgının ne zaman biteceğine yönelik belirsizliği artıran bir etken olmuştur.

Covid-19 salgınının Mart 2020 itibariyle ortaya çıkması, ilk çeyrekte büyümeye olan etkisini sınırlamıştır. 2020 yılı ilk çeyrek büyüme düzeyi \%4,6 olarak gerçekleşse de ilerleyen dönemlerde kapasite kullanım oranının düşmesi ve salgını durdurmaya yönelik tedbirlerin ekonomik etkilerinin, büyüme üzerinde olumsuz etkisi (Adıgüzel, 2020:217) sonucunda -\%10,3 gerçekleşmiştir. 2020 yılının ortalarından itibaren küresel ticaret hacmi ve sanayi üretiminde iyileşmenin başlaması, ekonomik büyüme anlamında Türkiye ekonomisinde olumlu etki oluşturmuştur. Ayrıca aşı konusundaki olumlu gelişmeler ve normalleşme adımları bu etkiyi güçlendirmiştir. Üçüncü çeyrekte $\% 6,3$, dördüncü çeyrekte $\% 5,9$ ve ortalama olarak \%1,8 büyüme ile 2020 y1lı tamamlanmıştır. 2020 yılında tarım ve sanayinde büyüme, inşaat ve hizmetler sektöründe daralma görülmüştür (SBB, 2021). Elde edilen bu büyüme rakamları ile Türkiye, 2020 yılında büyüme gösteren sınırlı ülkeler arasında yer almıştır.

Türkiye'de salgının yayılmasını önlemek üzere nispeten sınırlı kısıtlamalara rağmen, istihdam ve talep daralması büyük olmuştur. OECD 
(2020a) verilerine göre, Nisan ayından itibaren özel tüketim ve yatırımda $\% 20$ 'nin üzerinde bir daralma olduğu açıklanmıştır. Özellikle dış talebin ve yurtiçi ticaretin zayıflaması bu gerilemeyi arttırmıştır. Türkiye'de ağırlama sektörü tüm çalışanların \%8'ini istihdam etmekte, diğer ürün ve hizmetler için yoğun talep yaratmakta ve toplam ihracat gelirlerinin beşte birini güvence altına almaktadır. Salgın döneminde yerel ve bölgesel talep, turistik bölgelerde diğerlerine göre iki kat daha hızlı düşmüştür. Alışveriş merkezlerinin kapatılmasının da bu durum üzerinde etkileri olmuştur (OECD, 2020a).

Covid-19 krizi ekonomik dengeleri olumsuz yönde etkileyerek işsizlik üzerinde önemli etki oluşturmuştur. Türkiye'de devlet yasal düzenlemelerle işgücü piyasalarının esnekleştirilmesi sağlanarak işletmelerin rekabet gücü ve değişen şartlara uyumu sağlanırken, çalışanların istihdam ve gelir güvencesi sağlanmaya çalışılarak salgının işgücü piyasası üzerindeki olumsuz etkileri gidermeye çalışılmıştır. Yasal olarak esnek çalışma modeli, kısa çalışma ödeneği ve işten çıkarma yasağı uygulamaları hakkındaki düzenlemeler işgücü piyasası için düzenleyici bir uygulama olmuştur (Adıgüzel, 2020:218).

Salgın döneminde uluslararası sermaye hareketlerine bağlı olarak Türkiye'nin ülke risk primi artmış, Türk Lirası değer kaybetmiş ve kurlardaki oynaklık artmıştır (TCMB, 2020:7). Türk Lirası'nın son dönem değer kaybetmesi bu dönemde enflasyon beklentilerini arttırmıştır. Ancak, dünya petrol ve emtia fiyatlarındaki gerileme ve talepteki düşüş nedeniyle bu beklenti gerçekleşmeyerek enflasyon düzeyinde ciddi etki yapmamıştır (Adıgüzel, 2020:196). Salgından en çok etkilenen ülkeler arasında Türkiye'nin en önemli ticaret ortakları olan İran, Irak ve Avrupa ülkelerinin olması dış ticaret hacmini etkilemiştir. Bu ülkelerdeki salgının şiddeti nedeniyle Türkiye sınırları kapatma, seyahat kısıtlamaları ve karantina uygulamalarına gidilmesi ihracatın daralmasına neden olmuştur (TCMB, 2020:8).

\section{Literatür Çalışmaları}

Covid-19 salgını işgücü piyasalarında önemli etkiler ortaya çıkarmıştır. Yapılan çalı̧̧malarda salgın nedeniyle işgücü piyasasındaki eşitsizliklerin ve işsizliğin artması genel olarak kabul edilmektedir. Bu çalışmalardan biri Yılmaz vd. (2020) tarafından yapılan araştırma kapsamındaki görüşmeler sonucunda İstanbul'da çalışanlar arasında üç grubun salgından daha çok etkilendiği belirlemişlerdir. $\mathrm{Bu}$ gruptakiler işten çıkarma yasağı gelmeden çalıştıkları sektörün faaliyetleri durdurulanlar, kayıt dışı ücretli ve yevmiyeli çalışanlar, kendi hesabına çalışanları kapsamaktadır. Söz konusu bu grupta istihdam edilenler istihdamı korumaya yönelik önlemlerden faydalanamamışlardır. $\mathrm{Bu}$ nedenle salgın süreci, işgücü piyasasındaki eşitsizlikleri keskin bir şekilde ortaya çıkardığı sonucuna ulaşılmıştır. Bir başka çalışmada Dingel ve Neiman (2020), Covid-19 nedeniyle çalışanların seyahat edememesinin üzerinde durmuştur. $\mathrm{Bu}$ noktada politika yapıcılara yapılan tavsiye, sosyal sigorta ödemelerinin ihtiyaç olan alanlarda yapılması ve hangi işlerin evden yapılamayacağının 
belirlenmesinin gerekliliği olmuştur. Evde yapılacak bir işte çalışılırken, normal işyerinden önemli oranda farklılıklar görülür. Ayrıca, evde yapılan işler ve yapılamayan işler arasında bir tamamlayıcılık ilişkisi bulunduğuna dikkat çekilmiştir. Bu ilişkinin ise verimlilik artışı için bir alternatif olmasının altı çizilmiştir. Yılmaz (2020), kamu çalışanlarının Covid-19 salgınından nasıl etkilediğini araştırmıştır. Araştırma İstanbul Vergi Daire Başkanlığına bağlı olan 902 kamu personeline yapılmıştır. Elde edilen analiz sonuçlarına göre, vergi dairesi çalışanlarının Covid-19 salgınından olumsuz yönde etkilendiğini ortaya koymuştur. Özellikle çalışanlarda işe gidiş ve gelişlerde virüsün kendilerine dolayısıyla ailelerine bulaştırmalarından çekinmekte oldukları belirlenmiştir. Kamu çalışanlarının bu husustaki yüksek endişeleri nedeniyle uygun işlerin uzaktan çalışma yoluyla yapılmasına taraftar oldukları görülmüş̧ür. Bozkurt (2020), çalışmasında salgın sürecinin çalışma hayatındaki dijitalleşmeyi çok hızlı bir şekilde arttırdığını belirtmiş̧ir. Salgın sürecinin tüm insanları tehdit ettiğini ancak herkesin farklı düzeylerde etkilendiğini ifade etmiştir. Araştırmasında özellikle yoksullar, işsizler ve dezavantajlı grupların salgından daha fazla etkilendiği ortaya koymuştur. İşlerin dijital ortamda yapılması sağlandığında çalışanların kaygı düzeylerinin gerileyeceği belirtilmiştir. Delen ve Peksan (2020), sanayi işletmelerinde çalışan mavi yakalıların çalışma biçimlerindeki değişim, karşı karşıya kaldıkları Covid-19 kaynaklı riskler ve kaygı düzeylerini araştırmıştır. Sonuçlar mavi yakalı çalışanların ailelerine virüs bulaştırma korkusuna rağmen işlerini kaybetmemek için üretime devam ettikleri belirlenmiştir. Özellikle ailesinde hamile veya kronik hasta olanların kaygı ve korku düzeyinin daha yüksektir. Yöneticiler ve beyaz yakalılar evde kalırken mavi yakalıların çalışmak zorunda olması nedeniyle kendilerini daha değersiz hissetmiş̧lerdir.

\section{Covid-19 Salgınının İşgücü Piyasasına Etkileri Üzerine Bir Araştırma}

\subsection{Araştırmanın Amacı, Kapsamı ve Yöntemi}

Araştırmanın temel amacı işgücü piyasasının Covid-19 salgını sürecinde gösterdiği özellikleri tespit etmek olmuştur. Bu amaçla hazırlanan anket soruları Ankara, Kayseri, Konya, Sivas, Malatya, Yozgat şehirdeki aktif nüfus üzerine uygulanmıştır. Araştırmaya kaynaklık eden aktif nüfusun anket sorularını doğru algılayarak uygun bir şekilde yanıtladıkları varsayılmıştır. Araştırmada, virüsün devam eden bulaşma riski nedeniyle online anket yöntemi tercih edilmiştir. Çalışmanın örneklem büyüklüğü anketin uygulanacağı illerdeki çalışan sayısı belli olduğu için $n=\frac{N t^{2} p q}{d^{2}(N-1)+t^{2} p q}$ formülü ile hesaplanmıştır (Kılıç, 2012). Formülde; $N$ popülasyondaki birey sayısı, $n$ örnekleme alınacak birey sayısı, $p$ incelenecek olayın görülüş sıklığı, $q$ incelenecek olayın görülmeyiş sıklığı, $t$ belirli serbestlik derecesinde ve saptanan yanılma düzeyinde $t$ tablosunda bulunan teorik değer, $d$ olayın görülüş sıklığına göre yapılmak istenen + sapma olarak simgelenmiştir. 2019 y1lı verilerine göre örneklem olarak seçilen 6 il için 
toplam çalışan sayısı 4 milyon 49 bin olarak belirlenmiştir (TÜiK). Örneklem büyüklügü hesabı için $p=0,5, q=0,5$ ve $\mathrm{d}=0,05$ alınmıştır. Örneklem büyüklüğü $n$ belli olmadığ için serbestlik derecesi sonsuz $(\infty)$ alınarak $\alpha=0,05$ için $\mathrm{t}$ değeri 1,96 olarak belirlenmiştir. $\mathrm{Bu}$ değerlere göre yeterli örneklem büyüklüğü 385 olarak hesaplanmıştır. Yeterli örneklem büyüklüğü 385 olarak hesaplanmasına rağmen online olarak uygulanan ankete 1003 kişi katılmıştır. Örneklem büyüklügünün fazla olması, elde edilen sonuçların güvenilirliğini artırdığı için tüm katılımcılar çalışmaya dahil edilmiş̧ir. Anket sonuçlarından elde edilen tüm veriler SPSS 23 istatistik paket programıla değerlendirilmiştir. Çalışmaya katılan kişilerin demografik bilgilerine ait değerler verilmiştir. Ayrıca ölçekte yer alan diğer maddelere verilen cevaplar da say1 ve oran olarak sunulmuştur. Anket sonucu elde edilen verilerin frekans analizi yapılmıştır. Veriler cinsiyet, yaş ve sektörel açılardan çapraz tablolarla açıklanmıştır. İstatistiksel karşılaştırmalar Ki-kare analizi ile yapılmıştır.

\subsubsection{Katılimcilarla Illgili Demografik Özellikler}

Araştırma kapsamında yer alan katılımcılara ait tanımlayıcı istatistikler aşağıdaki Tablo1'de verilmiştir. Buna göre; çalışmada yer alan kadın ve erkek katılımcıların oranı dengeli olmakla birlikte kadın sayısı çoğunluktadır $(\% 51,9)$. Katılımcıların medeni durumlarına göre dağılımları incelendiğinde en çok katılımcının $(\% 57,8)$ evli olduğu görülmektedir. Katılımcıların eğitim seviyelerine bakıldığında çoğunluğun $(\% 58,8)$ üniversite mezunlarından oluştuğu görülmektedir. Katılımcılar yaş dağılımlarına göre incelendiğinde "2635 " $(\% 35,4)$ yaşındakilerin çoğunlukta olmakla birlikte, "16-25" (\%22,3) ile "3645 ” $(\% 25,6)$ yaşındakilerde önemli bir orana sahiptir. Ailesinde 4 birey bulunan katılımcılarının oranı $(\% 32,2)$ tüm katılımcılar içinde en yüksek düzeye sahiptir.

Tablo 1: Katılımcilara Ait Tanımlayıcı Ístatistikler

\begin{tabular}{|c|c|c|c|}
\hline Faktör & Değişken & $\mathbf{N}$ & $\mathbf{\%}$ \\
\hline \multirow{2}{*}{ Cinsiyet } & Kadın & 521 & 51,9 \\
\cline { 2 - 4 } & Erkek & 482 & 48,1 \\
\hline \multirow{2}{*}{ Medeni durum } & Evli & 580 & 57,8 \\
\cline { 2 - 4 } & Bekar & 423 & 42,2 \\
\hline \multirow{4}{*}{ Ĕgitim } & İlköğretim & 36 & 3,6 \\
\cline { 2 - 4 } & Lise & 126 & 12,6 \\
\cline { 2 - 4 } & Üniversite & 590 & 58,8 \\
\cline { 2 - 4 } & Yüksek Lisans & 152 & 15,2 \\
\cline { 2 - 4 } & Doktora & 9 & 9,9 \\
\hline \multirow{4}{*}{ Yaş } & $16-25$ & 224 & 22,3 \\
\cline { 2 - 4 } & $26-35$ & 355 & 35,4 \\
\cline { 2 - 4 } & $36-45$ & 257 & 25,6 \\
\cline { 2 - 4 } & $46-55$ & 130 & 13,0 \\
\cline { 2 - 4 } & $56-65$ & 32 & 3,2 \\
\cline { 2 - 4 } & 65 ve üzeri & 5 & 0,5 \\
\hline
\end{tabular}


Covid-19 Salgını Sürecinin İsgü̈cü Piyasaları Üzerine Etkisi: Uygulamalı Bir Araştırma

Tablo 1 Devamı: Katılımcılara Ait Tanımlayıcı Istatistikler

\begin{tabular}{|c|c|c|c|}
\hline \multirow{6}{*}{ Ailedeki birey sayısı } & 1 kişi & 28 & 2,8 \\
\hline & 2 kişi & 123 & 12,3 \\
\hline & 3 kişi & 267 & 26,6 \\
\hline & 4 kişi & 323 & 32,2 \\
\hline & 5 kişi & 164 & 16,4 \\
\hline & 6 kişi ve üzeri & 98 & 9,8 \\
\hline \multirow{2}{*}{ Çalışılan sektör } & Kamu sektörü & 470 & 46,9 \\
\hline & Özel sektör & 533 & 53,1 \\
\hline \multirow{8}{*}{ Çalışma alana } & Eğitim & 264 & 26,3 \\
\hline & Sağlık & 81 & 8,1 \\
\hline & İmalat sanayi & 54 & 5,4 \\
\hline & Ulaştırma & 22 & 2,2 \\
\hline & Perakende ticaret & 66 & 6,6 \\
\hline & $\begin{array}{l}\text { Kişisel bakım ve } \\
\text { spor }\end{array}$ & 9 & 0,9 \\
\hline & $\begin{array}{c}\text { Yemek ve } \\
\text { konaklama }\end{array}$ & 22 & 2,2 \\
\hline & Diğer & 485 & 48,4 \\
\hline \multirow{5}{*}{ Aylık gelir } & 1000 TL'den az & 47 & 4,7 \\
\hline & $1001-3000 \mathrm{TL}$ & 185 & 18,4 \\
\hline & $3001-5000 \mathrm{TL}$ & 233 & 23,2 \\
\hline & $5001-10000 \mathrm{TL}$ & 342 & 34,1 \\
\hline & 10001TL ve üzeri & 196 & 19,5 \\
\hline
\end{tabular}

\subsubsection{Katılımcıların Çalıştığı Sektörler ve Gelir Düzeyleri}

Ankete katılanların sektör bilgileri ve gelir düzeylerine yönelik bilgilere göre katılımcıların \%46,9'u (470) kamu sektöründe, \%53,1 (533) özel sektörde çalıştı̆̆ını bildirmiştir. Ankete katılanların \%26,3'ü (264) eğitim, \%8,1'i (81) sağlık, \%5,4'ü (54) imalat sanayi, \%2,2'si (22) ulaştırma, \%6,6's1 (66) perakende ticaret, \%0,9'u (9) kişisel bakım ve spor, \%2,2'si (22) yemek ve konaklama alanlarında ve geriye kalan \%48'4'ü (485) birey diğer alanlarda çalışmaktadır. Katılımcıların \%4,7'si 1000 TL'den az, \%18,4'ü 1001 TL-3000 TL, \%23,2'si 3000 TL-5000 TL, \%34,1'i 5001 TL-10000 TL ve \%19,5'i 10001 TL ve üzeri aylık gelire sahiptir. Katılımcıların \%51,8'i gelirinde bir azalma olmadığını, kalan \%48,2'side belirli oranlarda gelirinde azalış olduğunu belirtmiştir. Katılımcıların \%94,9'u gelirinde bir artış olmadığını, \%5,1'i de belli oranlarda artış olduğunu ifade etmiştir.

Veriler genel olarak değerlendirildiğinde salgın sürecinde istihdam olanaklarının kısıtlanmasının sonucu olarak aylık gelirlerde düşme olduğu izlenmektedir. Özellikle özel kesimde işyerlerinin kapanması, buraların sahiplerinin ve çalışanlarının ücretinde kayıplara neden olmuştur. Devlet çeşitli transfer harcamaları ve sübvansiyon destekleriyle bu olumsuzluğun etkisini azaltıcı politikalar uygulamıştır. Türkiye'de salgın nedeniyle oluşan arz şokunun 
etkilerini azaltmak üzere geniş bir yelpazede destek önlemleri uygulamaya konulmuştur. Salgın nedeniyle işlerini kaybeden, aşırı sıkıntıya düşen hane başına $1000 \mathrm{TL}$ tutarında acil yardım yapılmıştır. Ancak bu destek, yaşam standartlarını ve toplam talebi sadece sınırlı bir ölçüde desteklemiştir ve ekonominin genelinde oluşan durgunluk, gelir harcama mekanizmasının bozulmasına neden olmuştur. Çalışanların yanı sıra işletmelere verilen sübvansiyonlar büyük ölçüde devlet kredisi garantileri ve ihtiyati düzenlemeler şeklinde olmuştur. Kamu ve özel bankalar tarafından vergi ve kredi ertelemeleri, ek krediler yoluyla sağlanmıştır. Bu şekilde özel sektöre verilen desteklerle, iflaslardaki artışların hızının kesilmesi amaçlanmıştır. Kamu bankaları ayrıca serbest meslek sahiplerine ve ihtiyaçlı hane halklarına sübvansiyonlu kredi limitleri sunmuştur. Merkez bankası, genişletilmiş likidite pencereleri, bankalar için ek varlık indirimi olanakları ve genişletilmiş ihracat kredisi tesisi aracılığıyla finansal sistemin borç verme kapasitesini desteklemektedir (OECD, 2020b:321322). Bu tedbirlerle, Covid-19 salgınının ekonomide oluşan arz şokunun etkisi azaltılmaya çalışılmıştır.

\subsection{3. Çalışma Hayatındaki Değişim}

Covid-19 salgını sürecinde çalışma hayatıyla ilgili en dikkat çeken konulardan biri, bazı işlerin kesintiye uğrarken, fiziksel olarak uygun olan bazı işlerin devam etmesi hatta artış göstermesi olmuştur. Bu durumun tespit edilmesine yönelik elde edilen sonuçlar Tablo 2'de verilmiştir.

Tablo 2: Çalışma Hayatındaki Değişiklikler

\begin{tabular}{|l|c|c|c|c|}
\hline \multirow{2}{*}{} & \multicolumn{2}{|c|}{ Evet } & \multicolumn{2}{c|}{ Hayır } \\
\cline { 2 - 5 } & Sayı & Frekans & Sayı & Frekans \\
\hline Bu Dönemde İşsiz Kaldınız mı? & 227 & 22,63 & 776 & 77,37 \\
\hline Kamu Desteği Aldınız mı? & 101 & 10,07 & 902 & 89,93 \\
\hline Yeni İş Aradınız mı? & 252 & 25,12 & 751 & 74,88 \\
\hline $\begin{array}{l}\text { Bu Dönemde Çalışmayanlara (Maddi) } \\
\text { Destek Verdiniz mi? }\end{array}$ & 281 & 28,02 & 722 & 71,98 \\
\hline $\begin{array}{l}\text { Çalışma Düzeninde Farklı̈ık Olacağını } \\
\text { Düşünüyor musunuz? }\end{array}$ & 627 & 62,51 & 376 & 37,49 \\
\hline
\end{tabular}

Tablo 2'de ankete katılanların önemli bir yüzdesi bu dönemde işsiz kalmadığını belirtmiştir. Ancak \%22,63'lük bir dilim işsiz kaldığını belirtmiştir. Bu sonucun bir uzantısı olarak işsizlere verilen kamu desteğinden yararlanma ve salgın sonrası yeni iş arama yüzdeleri düşük çıkmıştır. Katılımcıların önemli bir oranı, bu dönemde çalışmayanlara maddi destekte bulunmadığını belirtmiştir. $\% 28$ 'lik kısım ise çalışmayanlara maddi destek sunduğunu belirtmiştir. Ayrıca, katılanların \%62,5'i Covid-19 salgını bittiğinde önceki çalışma düzenlerinden farklı bir düzende çalışacaklarını düşündüklerini belirtmişlerdir. 


\subsubsection{Covid-19 Salgını Sürecinde Evde Çalışma ve Esnek Çalışma} Biçimlerinin Etkileri

Covid-19 salgınında fiziki mesafenin önemli olması, esnek çalışma ve dolayısıyla evde çalışmayı zorunlu kılmıştır. Bu noktada gelecekte işgücü piyasalarının gideceği yön hakkında verimlilik, yeni istihdam alanları gibi konular üzerinde yoğun tartışmalar başlamıştır. Bir grup iktisatçı evden veya uzaktan çalışmanın, çalışma sürelerini kısaltarak verimliliğe katkı sağlayacağını savunmuştur. Bu görüşü destekleyenler ayrıca, evden çalışma yoluyla karbon emisyonunun azalmasına katkı sağlayarak, sürdürülebilir çevre konusunda katkı sağlayacağı görüşü desteklenmiştir. Bunun yanı sıra, diğer grup iktisatçılar evde çalışma uygulamalarının verimliliği azaltacağı fikrini savunmuştur (Ganong ve Noel, 2018:32). Bu noktada, çalışanların Covid-19 salgını sürecinde evde çalışma ve esnek çalışma biçimlerinin artmasıyla oluşacak ekonomik etkiler üzerindeki fikirleri üzerine elde edilen sonuçlar Tablo 3'te verilmiştir.

Tablo 3: Covid-19 Salgını Sürecinde Evde Çalı̧̧ma ve Esnek Çalışma Biçimlerinin Artmasının Ekonomiye Etkileri

\begin{tabular}{|c|c|c|c|c|c|c|c|c|c|c|}
\hline & $\begin{array}{r}\text { Ke } \\
\text { Katıl }\end{array}$ & $\begin{array}{l}\text { likle } \\
\text { yorum }\end{array}$ & Kat1lm & yorum & Kara & s1zım & Katılı & rorum & $\begin{array}{r}\text { Kes } \\
\text { Kat1l }\end{array}$ & $\begin{array}{l}\text { likle } \\
\text { orum }\end{array}$ \\
\hline & Say1 & $\%$ & Say1 & $\%$ & Say1 & $\%$ & Say1 & $\%$ & Say1 & $\%$ \\
\hline $\begin{array}{l}\text { Verimlilik } \\
\text { Artacaktır }\end{array}$ & 199 & 19,84 & 282 & 28,12 & 253 & 25,22 & 200 & 19,94 & 69 & 6,88 \\
\hline $\begin{array}{l}\text { Üretim } \\
\text { Artacaktır }\end{array}$ & 197 & 19,64 & 359 & 35,79 & 202 & 20,14 & 196 & 19,54 & 49 & 4,89 \\
\hline $\begin{array}{l}\text { Ücretler } \\
\text { Artacaktır }\end{array}$ & 227 & 22,63 & 357 & 35,59 & 169 & 16,85 & 154 & 15,35 & 96 & 9,57 \\
\hline $\begin{array}{l}\text { Yeni } \\
\text { İstihdam } \\
\text { Alanları }\end{array}$ & 115 & 11,47 & 158 & 15,75 & 189 & 18,84 & 427 & 42,57 & 114 & 11,37 \\
\hline $\begin{array}{l}\text { Çalışma } \\
\text { Süresinin } \\
\text { Kısalması }\end{array}$ & 191 & 19,04 & 310 & 30,91 & 182 & 18,15 & 271 & 27,02 & 49 & 4,89 \\
\hline $\begin{array}{l}\text { İşsizlik } \\
\text { Azalacaktır }\end{array}$ & 382 & 38,09 & 334 & 33,30 & 136 & 13,56 & 106 & 10,57 & 45 & 4,49 \\
\hline 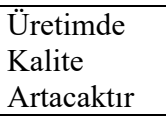 & 212 & 21,14 & 357 & 35,59 & 246 & 24,53 & 155 & 15,45 & 33 & 3,29 \\
\hline $\begin{array}{l}\text { Kayıt Dışı } \\
\text { İstihdam } \\
\text { Azalacaktır }\end{array}$ & 233 & 23,23 & 347 & 34,60 & 253 & 25,22 & 134 & 13,36 & 36 & 3,59 \\
\hline $\begin{array}{l}\text { Kadınlar } \\
\text { İşgücü } \\
\text { Piyasasına } \\
\text { Daha Fazla } \\
\text { Katılacaktır }\end{array}$ & 138 & 13,76 & 268 & 26,72 & 293 & 29,21 & 250 & 24,93 & 54 & 5,38 \\
\hline
\end{tabular}


Tablo 3'e göre, katılımcıların çoğunluğu evde çalışma ve esnek çalışma saatlerinin, verimliliği, üretimi ve ücretleri artırmayacağını, yeni istihdam alanları oluşturacağını, çalışma sürelerinin kısalmayacağını, üretimde kalitenin artmayacağını, kayıt dışı istihdamın azalmayacağını ifade etmiş̧lerdir. İşsizliğin azalması konusunda büyük çoğunluk kesinlikle katılmamaktadır. Kadınların işgücü piyasasında daha fazla yer alması konusunda ise kararsız olanlar çoğunluktadır. Bu durum kadın istihdamının istenilen düzeye ulaşmaması ve erkek istihdamının geleneksel olarak daha fazla tercih edilmesiyle açıklanabilir.

\subsubsection{Covid-19 Salgını Nedeniyle Çalışma Şartlarındaki Değişiklikler}

Covid-19 salgını, fiziki mesafenin bulaşma üzerinde etkili olması karantina uygulamasını zorunlu kılmıştır. Türkiye'de dünyadakine benzer şekilde Covid19 salgını sırasında uygulanan temel kamu politikası sosyal mesafe olmuştur. Sosyal mesafe uygulamasının ekonomik sonucu, birçok çalışanın evden çalışma düzenine geçmesi olmuştur (Mongey vd., 2020:1). Bu durum özellikle dijital teknolojilerin de imkan verdiği ölçüde, evde çalışma ve esnek çalışma biçimlerinin uygulandığı bir süreci getirmiştir (Ganong ve Noel, 2018:32). Tablo 4 'te çalışanların Covid-19 salgını sürecinde çalışma şartlarındaki değişimleri belirlemek üzere hazırlanan sorulara verilen cevaplar yer almaktadır.

Tablo 4: Covid-19 Salgını Sürecinde Çalışma Şartlarındaki Değişmeler

\begin{tabular}{|l|c|c|c|c|c|c|}
\hline \multirow{2}{*}{} & \multicolumn{2}{|c|}{ Arttı } & \multicolumn{2}{c|}{ Değişmedi } & \multicolumn{2}{c|}{ Azaldı } \\
\cline { 2 - 7 } & Sayı & \% & Sayı & \% & Sayı & \% \\
\hline $\begin{array}{l}\text { Evde Çalışma } \\
\text { Süresi }\end{array}$ & 635 & 63,31 & 292 & 29,11 & 76 & 7,58 \\
$\begin{array}{l}\text { Günlük Çalışma } \\
\text { Saati }\end{array}$ & 267 & 26,62 & 325 & 32,40 & 411 & 40,98 \\
\hline $\begin{array}{l}\text { Çalışma } \\
\text { Motivasyonu }\end{array}$ & 143 & 14,26 & 244 & 24,33 & 616 & 61,42 \\
\hline $\begin{array}{l}\text { Çalışma Verimliliği } \\
\begin{array}{l}\text { İs Arkadaşlarınızla } \\
\text { Görüşme Süreleri }\end{array}\end{array}$ & 166 & 16,55 & 251 & 25,02 & 586 & 58,42 \\
\hline $\begin{array}{l}\text { Yöneticilerle } \\
\text { Görüşme Süreniz }\end{array}$ & 102 & 7,48 & 132 & 13,16 & 796 & 79,36 \\
\hline Gelir Seviyeniz & 33 & 3,29 & 585 & 58,33 & 385 & 38,38 \\
\hline Tasarruf Oranı & 374 & 37,29 & 328 & 32,70 & 301 & 30,01 \\
\hline Yeni Proje Fikirleri & 285 & 28,41 & 410 & 40,88 & 308 & 30,71 \\
\hline $\begin{array}{l}\text { Gelir Kaybı } \\
\text { Yardımları }\end{array}$ & 444 & 44,27 & 365 & 36,39 & 194 & 19,34 \\
\hline
\end{tabular}

Katılımcılar büyük oranda Covid-19 salgını sürecinde evde çalışma sürelerinin, tasarruf ve yatırımlarının arttığını belirtmiştir. Bununla birlikte günlük çalışma saatinde, çalışma motivasyonunda, verimlilikte, iş arkadaşlarıyla görüşme sürelerinde ve yöneticilerle görüşme yoğunluklarında azalma olduğunu belirtenler de büyük orandadır. Bu durum, işgücü piyasasının psikolojik ve sosyal 
çevreyle olan ilişkisini vurgulamaktadır. İşgücü piyasasına dahil olanlar, zamanlarının önemli kısmını iş yerlerinde geçirmektedir. Ayrıca çalışanlar, iş dışındaki zamanlarını da gerekli beceriler kazanmak üzere kullanmaktadır (Işığıçok, 2017:3). Herkesin ev ortamı fiziki ve teknolojik açıdan aynı şartlarda olmadığından, bu durum da verimliliği azaltan ve haksız rekabete yol açan koşullar ortaya çıkaracaktır. Dolayısıyla, çalışırken geçirilen uzun süreler sadece iş ilişkileri açısından değil sosyal ilişkiler açısından da oldukça önemlidir. Karantina döneminde, fiziken bir iş yerinde çalışmanın bu kapsamdaki önemi oldukça net bir şekilde ortaya çıkmıştır. Bunlara ek olarak katılımcılar, gelir seviyesi ve proje fikirlerinde bir değişiklik olmadığını belirtmiştir. Gelir seviyesinin değişmediğini belirten büyük çoğunluğa rağmen, azaldığını belirtenler de önemli orandadır (\%38). Gelir seviyeleri azalırken tasarrufun artmas1, harcamalardaki düşüşün etkisi olarak değerlendirilebilir. Salgın sürecinde zaruri ihtiyaçlarını karşılamaya yönelen tüketicilerin toplam harcama düzeylerinin azalması nedeniyle, gelirlerinin kullanılmayan kısmını temsil eden tasarrufları arttırmıştır.

\subsubsection{Covid-19 Salgınında Günlük Hayattaki Değişimler}

Çalışanların Covid-19 salgını sürecinde günlük yaşamında ortaya çıkan değişimleri belirlemek ve zamanlarını nasıl geçirdiklerini ortaya koymak amaciyla hazırlanan sorulara katılımcıların verdiği cevaplar Tablo 5'te verilmiştir.

Tablo 5: Covid-19 Salgını Sürecinde Günlük Yaşamda Ortaya Çıkan Değişimler

\begin{tabular}{|c|c|c|c|c|c|c|}
\hline & \multicolumn{2}{|c|}{ Arttı } & \multicolumn{2}{|c|}{ Değişmedi } & \multicolumn{2}{|c|}{ Azaldı } \\
\hline & Sayı & $\%$ & Sayı & $\%$ & Sayı & $\%$ \\
\hline $\begin{array}{l}\text { Evde Temizlik İşlerine Ayrılan } \\
\text { Süre }\end{array}$ & 832 & 82,95 & 159 & 15,85 & 12 & 1,20 \\
\hline Yemek Yapmak İçin Ayrılan Süre & 812 & 80,96 & 183 & 18,25 & 8 & 0,80 \\
\hline $\begin{array}{l}\text { Diğer Aile Bireylerine Ayrilan } \\
\text { Süre }\end{array}$ & 785 & 78,27 & 138 & 13,76 & 80 & 7,98 \\
\hline Spor Yapmaya Ayrilan Süre & 490 & 48,85 & 358 & 35,69 & 155 & 15,45 \\
\hline Kitap Okumaya Ayrılan Süre & 634 & 63,21 & 296 & 29,51 & 73 & 7,28 \\
\hline Hobilere Ayrilan Süre & 626 & 62,41 & 294 & 29,31 & 83 & 8,28 \\
\hline Sosyal Medya İle İlgilenilen Süre & 770 & 76,77 & 194 & 19,34 & 39 & 3,89 \\
\hline $\begin{array}{l}\text { Gündem ve Haber İzlemeye } \\
\text { Ayrilan Süre }\end{array}$ & 824 & 82,15 & 144 & 14,36 & 35 & 3,49 \\
\hline Günlük Koşturma-Telaşlar & 323 & 32,20 & 204 & 20,34 & 476 & 47,46 \\
\hline Dinlenmeye Ayrılan Süre & 636 & 63,41 & 207 & 20,64 & 160 & 15,95 \\
\hline
\end{tabular}

Katılımcılar, Covid-19 salgını karantina döneminde temizlik, yemek, spor, kitap okuma, hobiler, sosyal medya, haberler, aile bireyleri ve dinlenmeye daha çok zaman ayırdıklarını belirtmiştir. Dışarda yapılan günlük işlerin ise azaldığııı belirtmişlerdir. Bu cevaplar, zorunlu karantina uygulamasının bir 
sonucu olarak ortaya çıkmıştır. Özellikle yoğun çalışma temposu içerisinde sosyal faaliyetlere zaman ayıramayan işgücü için farklı bir süreç olmuştur.

\subsection{Araştırma Verilerinden Elde Edilen Bulgular}

Salgın süresince evde çalışma ve esnek çalışma biçimlerinin artmasının ekonomiye etkileri konusunda çalışanların görüşleri alınmıştır. Çalışanların yaşları, cinsiyetleri ve çalıştıkları sektörlerin görüşleri üzerinde farklılık oluşturup oluşturmadığ1 incelenmiştir. Yine bu süreçte çalışma şartlarındaki değişiklikler ile çalışanların yaşları, cinsiyetleri ve çalıştıkları sektörler arasında ilişki durumunun belirlenmesi amaçlanmıştır. Araştırma sonucunda elde edilen verileri yaş, sektör ve cinsiyet kategorilerinde daha kapsamlı değerlendirmek üzere Ki-kare testi yapılmıştır. Elde edilen bulgular aşağıdaki tablolarda verilmiştir.

Tablo 6: Sektör ile Diğer Değişkenlerin Ki-kare Testi Sonuçları

\begin{tabular}{|l|c|c|}
\hline \multicolumn{1}{|c|}{ Karşılaştırılan değişkenler } & Ki-kare değeri & p \\
\hline Çalışılan Sektöre göre Salgın Sonrası Çalışma Düzeni & 23,148 & 0,000 \\
\hline Farklı Sektörlerin Verimlilik Üzerine Görüşleri & 2,346 & 0,672 \\
\hline Sektörler ve Yeni Proje Fikri & 42,146 & 0,000 \\
\hline Sektör ve İ̧ Arkadaşlarlyla Görüşme Süreleri & 3,017 & 0,221 \\
\hline Sektörler ve Günlük Çalışma Saati & 20,321 & 0,000 \\
\hline Sektörler ve Çalışma Motivasyonu & 1,267 & 0,531 \\
\hline Sektörler ve Kadınların İş Gücü Piyasasındaki Yeri & 5,035 & 0,284 \\
\hline Sektörler ve Üretimin Artması & 4,747 & 0,314 \\
\hline
\end{tabular}

Salgın süresince hem özel hem de kamu sektöründe çalışanların çalışma düzeninde ve çalışma zamanlarında değişikliğe gidilmiştir. Bu değişiklikler sektörlere göre kısmen veya tamamen uygulanmıştır. Yeni çalışma düzeninin çalışanlar üzerinde olumlu ve olumsuz etkileri olmuştur. Bu etkiler salgın öncesindeki mevcut çalışma sistemlerinin gözden geçirilmesine firsat tanımıştır. Buna bağlı olarak salgın sonrasında çalışma düzenlerinde değişikliğe gidilip gidilmeyeceği yönündeki beklentileri sorulmuştur. Çalışılan sektör ile değişiklik konusundaki beklentileri arasındaki ilişki "Ki-kare bağımsızlık testi" ile test edilmiştir. Katılımcıların çalıştıkları sektörle beklentileri arasında ilişki olduğu belirlenmiştir $(p<0,05)$. Tablo 6'ya göre özel sektörde çalışanların kamu sektöründe çalışanlara göre değişiklik beklentisi daha fazladır.

Katılımcilara, salgın sürecinde yeni proje fikirlerinde değişim olup olmadığı sorulmuştur. Verilen cevaplara göre, katılımcının çalıştığı sektör ile yeni proje üretme durumu arasında ilişki olduğu belirlenmiştir $(p<0,05)$. Kamu sektöründe çalışanların özel sektördeki çalışanlara göre daha çok yeni proje fikrine sahip oldukları görülmüştür (Tablo 6).

Salgın sürecinde günlük çalışma saatlerinde değişim olup olmadığ sorusuna verilen cevaplara göre, katılımcının çalıştığ 1 sektör ile günlük çalışma saatleri arasında ilişki olduğu görülmüştür $(p<0,05)$. Daha çok kamu sektöründeki çalışanların günlük mesai saatlerinde artış görülmüştür (Tablo 6). 
Çalışılan sektör türüyle verimliliğin artacağı düşüncesi, iş arkadaşlarıyla görüşme sürelerinin değişimi, çalışma motivasyonlarının değişimi, kadınların iş gücü piyasasında daha çok yer alması düşüncesi ve üretimin artış durumu arasında ilişki olmadığı görülmüştür ( $>0,05)$ (Tablo 6). Hem kamu sektörü hem de özel sektördeki çalışanların tüm bu konular üzerinde benzer görüş bildirmişlerdir.

Tablo 7: Yaş ile Diğer Değişkenlerin Ki-kare Testi Sonuçları

\begin{tabular}{|l|c|c|}
\hline \multicolumn{1}{|c|}{ Karşılaştırılan değişkenler } & Ki-kare değeri & p \\
\hline Yaşve Verimlilik & 24,667 & 0,002 \\
\hline Yaşve Yeni Proje Fikri & 11,782 & 0,161 \\
\hline Yaşve Çalışma Motivasyonu & 8,258 & 0,409 \\
\hline Yaşve Günlük Çalışma Saati & 14,405 & 0,072 \\
\hline Yaşve Kadınların İsücü Piyasasında Daha Çok Yer Alması & 15,181 & 0,028 \\
\hline Yaşve Üretimin Artması & 8,156 & 0,385 \\
\hline Yaşve Ücretlerde Artış & 50,282 & 0,000 \\
\hline
\end{tabular}

Katılımcılara, salgın sürecinde evde çalışma ve esnek çalışma biçimlerinin artmasının verimlilik üzerindeki etkisi konusunda ne düşündükleri sorulmuştur. Verilen cevaplara göre, çalışanın yaşı ile verimliliğin artacağı düşüncesi arasında ilişki olduğu belirlenmiştir $(p<0,05)$. Yaş olarak daha büyük olan çalışanlar, esnek ve evde çalışma sisteminin verimliliği artırmayacağı yönünde görüş bildirmişlerdir (Tablo 7).

Salgın sürecinde evde çalışma ve esnek çalışma biçimlerinin artmasının, kadınların işgücü piyasasına daha fazla katılmalarına olanak sağlayıp sağlamadığı sorulmuştur. Katılımcıların yaşı ile verdikleri cevaplar arasında ilişki olduğu ortaya çıkmıştır $(p<0,05)$. Yaş gruplarına baktığımızda $26-35$ yaş aralığında yer alan kişiler kadınların iş gücü piyasasında daha çok yer alabileceğini düşünmektedir (Tablo 7).

Salgın sürecinde evde çalışma ve esnek çalışma biçimlerinin artmasının, ücret artışına neden olup olmayacağı sorulmuştur. Katılımcıların yaşı ile verdikleri cevaplar arasında ilişki olduğu ortaya çıkmıştır $(p<0,05)$. Yaş gruplarına baktığımızda, yaşı büyük olan çalışanlarda ücret artışı olmayacağı düşüncesi daha fazladır (Tablo 7).

Katılımcıların bulunduğu yaş grubu ile yeni proje fikirlerindeki değişim, çalışma motivasyonunda değişim, günlük çalışma saatlerinde değişim ve üretim artışı arasında ilişki olmadığı belirlenmiştir ( $\mathrm{p}>0,05)$ (Tablo 7). Bu konular için tüm yaş gruplarındaki çalışanlar benzer şekilde görüş bildirmişlerdir.

Tablo 8: Cinsiyet ile Diğer Değişkenlerin Ki-kare Testi Sonuçlar

\begin{tabular}{|l|c|c|}
\hline \multicolumn{1}{|c|}{ Karşılaştırılan değişsenler } & Ki-kare değeri & p \\
\hline Cinsiyete ve Çalışma Saati & 0,945 & 0,624 \\
\hline Cinsiyet ve Kadınların İşü̈ü Piyasasında Daha Çok Yer Alması & 7,597 & 0,108 \\
\hline Cinsiyetin ve Üretimin Artması & 5,685 & 0,058 \\
\hline
\end{tabular}


Salgın sürecinde evde çalışma ve esnek çalışma biçimlerinin artmasının, üretimde artış sağlayıp sağlamayacağı sorusuna verilen cevaplar ile cinsiyet arasında ilişki olmadığı ortaya çıkmıştır ( $\mathrm{p}>0,05)$ (Tablo 8).

Katılımcıların cinsiyeti ile günlük çalışma saatlerinde değişim ve kadınların işgücü piyasasında daha fazla yer alması düşünceleri arasında ilişki olmadığı belirlenmiştir ( $p>0,05)$ (Tablo 8). Bu konular için tüm yaş gruplarındaki çalışanlar benzer şekilde görüş bildirmişlerdir.

\section{Sonuç}

Küresel sağlık krizine yol açan Covid-19 salgını, önemli ekonomik sorunların ortaya çıkmasına sebep olmuştur. Salgının dünya üzerinde bu kadar yayılması, artan vaka ve ölümler, aşılanma süresi ve üçüncü dalganın da ortaya çıkması ekonomideki belirsizliği artırarak bu etkilerin derinleşmesine neden olmuştur. $\mathrm{Bu}$ noktada devletlerin salgını kontrol etmek üzere uyguladığı tedbirlerin ekonomik maliyeti giderek artmaktadır. Zorunlu olarak uygulanan bu durum, üretim açısından önemli kayıpları ifade etmektedir. İşgücü piyasasından bu şekilde belirli süre çekilmek zorunda kalan çalışanlar, yetenek kaybı sorunuyla da karşı karşıya kalacaktır. Bu nedenle, işe geri dönüşlerde çalışanlarda adaptasyonu ve verimliliği arttırmak amacıyla, eğitim ve motivasyon faaliyetleri yürütülmesi faydalı olacaktır.

Türkiye'de işgücü piyasasını düzenleme kapsamında yapılan çeşitli uygulamalar olmuştur. Bu noktada özellikle fiziki mesafenin korunamadığ sektördeki faaliyetler durdurulmuştur. Türkiye'de alınan bu tedbirlerin özel sektör ve kamu sektörü anlamında uygulamalarda farklılıklar ortaya çıkmıştır. $\mathrm{Bu}$ anlamda ilk farklılık getirilen esnek çalışma uygulaması kamu sektörü çalışanlarına kolaylıkla uygulanmış ancak özel sektör çalışanlarına uygulanmasında sorunların ortaya çıtığı görülmüştür. İşçi-işveren kesimlerinin farklı1ı̆̆ bu uygulamada belirgin biçimde görülmüştür. İkinci olarak karantina döneminde kamu çalışanları gelir olarak bir kayba uğramazken, özel sektör çalışanlarının hızlı bir şekilde gelir kaybına uğradığı görülmüsşür. Bu noktada mağdur olan kişiler çeşitli kamu desteklerinden faydalandırılmıştır. Üçüncü olarak kamu sektöründe üretim kaybına bakılmaksızın işten çıkarma yapılmamış özel sektörde ise işverenler hızlıca bu girişimde bulunmuştur. Bu noktada yine kamu otoritesi devreye girerek gerekli düzenlemeleri yapsa da işten çıkarmaların önüne tamamen geçilememiş̧ir. Dolayısıyla Türkiye işgücü piyasası temel problemlerinden biri olan kamu istihdamının yüksek olması, bu sağlık krizinde avantajları anlamında özel sektörün önüne geçmiştir.

Covid-19 salgınının işgücü piyasasındaki etkileri doğrultusunda genel çıkarımlar şu şekilde olmuştur:

- Covid-19 salgını öncelikle işgücü anlamında önemli kaybı ifade etmektedir. Dünya genelinde gerek virüsten etkilenerek hastalık süreci geçiren gerekse hayatını kaybederek işgücü piyasasında eksiklik oluşturanlar açısından Covid-19 salgını önemli etki yapmıştır. 
- Covid-19 salgını nedeniyle küresel tedarik zincirinin aksaması üretimde önemli kesintilere yol açarak işgücü piyasasının olumsuz etkilenmesine neden olmuştur.

- Covid-19 salgınının yayılmasını kontrol etmek amacıyla devletlerin aldığı çeşitli yoğunluktaki koruma tedbirleri farklı derecelerde ülke işgücü piyasalarına olumsuz etki etmiştir.

- Covid-19 salgını belirli sektörlerde büyük kayıp oluştururken, bazı sektörlerde evden çalışma imkanıyla iş faaliyetlerinin yürütülebildiği görülmüştür. $\mathrm{Bu}$ koşullarda işler yürütülmekle birlikte; çalışma süresi, yetki alanı, mesai kavramı ya da ek mesai ödemeleri gibi konular üzerine sorunların arttığı görülmektedir. Bu noktada gerekli yasal düzenlemelerin yapılması, işgücü piyasasının düzenlenmesi anlamında oldukça önemlidir (Yorğun, 2020:106). Ancak yasal düzenlemelerin yapılmas1 ve uygulamaya başlamasındaki uyum problemleri, işgücü piyasasında bu anlamda esnekliği azaltıcı unsur olarak ortaya çıkmaktadır.

- Eğitim-öğretim faaliyetlerinin zorunlu olarak uzaktan eğitimle yürütülmesi, işgücünün eğitim ve beceri açısından ilerleyen dönemlerde eksiklikler yaşayacağı düşünülmektedir.

Covid-19 salgınının işgücü piyasasındaki etkileri doğrultusunda yapılan anket doğrultusunda özel çıkarımlar ise şu şekildedir:

- İş dünyasında özellikle özel sektörde genel olarak beklenen kısa süreli ve evden çalışma biçimlerinin ileriki dönemlerde artacağ 1 öngörüleri, yapılan analizde desteklenmemektedir. Araştırmaya katılanların büyük çoğunluğu verimliliğin, motivasyonun ve üretimin azalacağını belirtmektedirler. $\mathrm{Bu}$ görüşler bireylerin işsiz kalma ve hak kaybına uğrama endişene bağl1 olarak ta ortaya çıkmaktadır. Buna bağlı olarak, ileriki dönemlerde evden ve esnek zamanlı çalışmaların yaygınlaşması durumunda, bunun fiziki ve kanuni altyapısının ve sağlam oluşturtulması gerekmektedir.

- İş arkadaşlarıyla ve yöneticilerle görüşme sürelerinin azalması, bilgi ve tecrübelerin paylaşılamaması ya da örgüt kültürü gücünün zayıflaması gibi konularda olumsuz sonuçlara sebep olabilmektedir. Salgından sonraki dönemlerde çalışanlar ve yöneticiler arasındaki ilişkileri yeniden düzene koyabilmek üzere, adaptasyon süreçleri yaşanabilir.

\section{Kaynaklar}

Adıgüzel, M. (2020). Covid-19 Pandemisinin Türkiye Ekonomisine Etkilerinin Makroekonomik Analizi, İstanbul Ticaret Üniversitesi Sosyal Bilimler Dergisi Covid-19 Sosyal Bilimler Özel Saylsı, 19(37) (Özel Ek), 191-221.

Baker, S. R., Farrokhnia, R. A., Steffen, M., Pagel, M. and Yannelis, C. (2020). Income, Liquidity, and the Consumption Response to the 2020 Economic Stimulus Payments, Becker Friedman Institute, Working Paper, 2020-55. 
Bartik, A. W., Bertrand, M., Cullen, Z. B., Glaser, E. L., Luca, M. and Stanton, C. T. (2020). How Are Small Businesses Adjusting to COVID-19? Early Evidence from a Survey, Becker Friedman Institute, Working Paper, 202042.

Barrot, J. N., Grassi, B. and Sauvagnat, J. (2020). Sectoral Effects of Social Distancing, HEC Paris Research Paper, No.FIN-2020-1371.

Bozkurt, V. (2020). Pandemi Döneminde Çalışma: Ekonomik Kaygılar, Dijitalleşme ve Verimlilik, COVID-19 Pandemisinin Ekonomik, Toplumsal ve Siyasal Etkileri, Ed: Dilek Demirbaş, Veysel Bozkurt, Sayım Yorğun, İstanbul Üniversitesi Yayınevi, İstanbul.

Chao, S. P. (2020). Simplified Model on the Timing of Easing the Lockdown, Papers 2007.14072, arXiv.org.

Delen, M. G. ve Peksan, S. (2020). COVID-19 ve İşçiler Salgının İlk Döneminde Sanayi İşletmelerinde Çalışan İşçiler (Mavi Yakalılar), İÜ İktisat Fakültesi İnsan Kaynakları Araştırma Merkezi, Erişim Adresi: https://cdn.istanbul.edu.tr/FileHandler2.ashx?f=ikam-mavi-yakalilarrapor.pdf, Erişim Tarihi: 12.09.2020.

Dingel, J. I. and Neiman, B (2020). How Many Jobs Can be Done at Home?, Becker Friedman Institute White Paper.

Ganong, P. and Noel, P. (2018). Consumer Spending During Unemployment: Positive and Normative Implications, Becker Friedman Institute, Working Paper, 2019-89.

Gerschel, E., Martinez, A., and Mejean, I. (2020). Propagation of Shocks in Global Value Chains: The Coronavirus Case, Institut des Politiques Publiques, IPP Policy Brief n53.

Guerrieri, V., Lorenzoni, G. Straub, L. and Werning, I. (2020). Macroeconomic Implications of Covid-19: Can Negative Supply Shocks Cause Demand Shortages?, NBER Working Paper Series, No.26918.

ILO (2020), ILO: Monitor: COVID-19 and the World of Work, Sixth Edition, 23 September 2020.

Işı̆̆ıçok, Ö. (2017), İstihdam ve İssizizlik, Dora Basım-Yayın, Bursa.

Karagöz, F. (2020). Pandeminin Küresel Tedarik Zincirlerinin İsleyişine Etkisi ve Muhtemel Sonuçlart Üzerine Bir Değerlendirme, COVID-19 Pandemisinin Ekonomik, Toplumsal ve Siyasal Etkileri, Ed: Dilek Demirbaş, Veysel Bozkurt, Sayım Yorğun, İstanbul Üniversitesi Yayınevi, İstanbul.

K1lıç, S. (2012). Örnek Büyüklüğü, Güç Kavramları ve Örnek Büyüklüğü Hesaplamas1, Journal of Mood Disorders, 2(3), 140-142.

Mongey, S., Pilossoph, L. and Weinberg, A. (2020). Which Workes Bear the Burden of Social Distancing Policies?, Becker Friedman Institute, Working Paper, No.2020-51.

OECD (2020a). Coronavirus: The World Economy at Risk, Access Address: https://www.oecd-ilibrary.org/docserver/7969896b- 
Covid-19 Salgını Sürecinin İsgü̈cü Piyasaları Üzerine Etkisi: Uygulamalı Bir Araştırma

en.pdf?expires $=1593514503 \& \mathrm{id}=\mathrm{id} \&$ accname $=$ guest\&checksum $=721960$ BF5DEA19855FFF17374BB83739, Date of Access: 30.06.2020.

OECD, (2020b). "OECD Economic Outlook June 2020", Access Address: https://www.oecd-ilibrary.org/docserver/0d1d1e2e-

en.pdf?expires $=1593514547 \& \mathrm{id}=\mathrm{id} \&$ accname $=$ guest $\&$ checksum $=6 \mathrm{EE} 51$ 955D9C7E3F4268545B7132E6CD3, Date of Access: 30.06.2020.

Piguillem, F. and Shi, L. (2020). The Optimal COVID-19 Quarantine and Testing Policies, EIEF Working Paper, 20/04.

Rio-Chanona, R. M., Mealy, P., Pichler, A., Lafond, F. and Farmer, J. D. (2020). Supply and Demand Shocks in the COVID-19 Pandemic: An Industry and Occupation Perspective, Covid Economics, Centre for Economic Policy Research Press, 65-103.

SBB, (2021). GSYH Büyüme Oranları, Erişim Adresi: https://www.sbb.gov.tr/buyume/, Erişim Tarihi: 21.03.2021.

TCMB, (2020). Enflasyon Raporu 2020-II, ISSN 1306-4509, Ankara.

WHO, (2021). Erişim Adresi: https://www.who.int/emergencies/diseases/novelcoronavirus-2019, Erişim Tarihi: 22.04.2021.

Yılmaz, B. (2020). COVID-19 Pandemi Sürecinin Çalışanlar Üzerine Etkisi: Kamu Sektöründe Çalışanlar Üzerine Uygulamalı Bir Araştırma, Üçüncü Sektör Sosyal Ekonomi Dergisi, 55(3), 1724-1740.

Yılmaz, V., Gürbüztürk, A., Canbazer, C., Ekici, E., Hışıl, O., Aktaş, P., Aslan, R. G., Serim, S., Şen, T. Z. ve Kesici, Z. (2020). COVID-19 Salgınında İstanbul'da Çalışanların Deneyimleri: Niteliksel Bir İnceleme, Boğaziçi Üniversitesi Sosyal Politika Forumu, Erişim Adresi: https://spf.boun.edu.tr/sites/spf.boun.edu.tr/files/SPF COVID19 Rapor.p df, Erişim Tarihi: 02.10.2020.

Yorğun, S. (2020). COVID-19 Salgını'nın Sosyal Politikalara Etkileri, Ed: Dilek Demirbaş, Veysel Bozkurt, Sayım Yorğun, İstanbul Üniversitesi Yayınevi, İstanbul. 